J. v.A. Robey ${ }^{1}$, J.W. Bristow ${ }^{1}$, M.R. Marx $^{2}$, J. Joyce ${ }^{2}$, R.V. Danchin ${ }^{2}$ and F. Arnot ${ }^{2}$

1. Geology Department, De Beers Consolidated Mines Limited, P.0. Box 47, Kimberley, 8300 , R.S.A.

2. Stockdale Prospecting, 60 Wilson Street, South Yara V3141, Australia.

\title{
INTRODUCTION
}

In 1979 Stockdale Prospecting Ltd. recovered kimberlitic ilmenites from reconnaissance loam samples taken in the Fraser Range area some $100 \mathrm{~km}$ east of Norseman. Subsequent detailed follow-up sampling, ground magnetic surveys and core drilling showed the primary source of these ilmenites to be two dykes, named ANI and AN10.

This paper details the petrological, geochemical and geochronological studies undertaken on fresh drill core from the AN10 dyke.

\section{REGIONAL GEOLOGY}

The dykes are situated some $10 \mathrm{~km} \mathrm{SE}$ and $70 \mathrm{~km} \mathrm{E}$ of Norseman respectively. This area straddles the margin between the south-eastern edge of the Archaean Yilgarn craton and the adjacent Proterozoic Fraser Range belt.

AN10 is intruded through an Archaean section of granites dated at approximately $2615 \mathrm{~m} . \mathrm{y}$. Greenstone belts occur further to the west. Early Proterozoic unmetamorphosed basic to ultrabasic dykes of the Widgiemooltha Dyke Suite occur within the Archaean of this area.

In contrast the Proterozoic section through which ANl is intruded consists of garnet gneisses of the Mount Andrew Migmatite Complex with basic and acid granulites and gneisses of the Fraser Complex occurring further to the east. Rocks of both these complexes range in age from $1210 \mathrm{~m} . \mathrm{y}$. to $1680 \mathrm{~m} . \mathrm{y}$. Deformed basic to ultrabasic bodies of a noritic affinity are widespread within the gneisses and granulites of the Fraser belt. They have not been accurately dated but are thought to be early Proterozoic and are probably correlated to the Widgiemooltha dykes.

\section{PETROLOGY}

The ANl dyke strikes east-northeast and based on the ground magnetic anomaly is $600 \mathrm{~m}$ in length and vertical. Dyke widths determined in two drill intersections vary from 1 to $10 \mathrm{~m}$.

The AN10 dyke, further to the west, strikes west-northwest and based on the surface ilmenite anomaly, is probably an en echelon set $10 \mathrm{~km}$ in length. A dyke width of $1 \mathrm{~m}$ was calculated from an intersection between 62 and $65 \mathrm{~m}$ in an angled drill hole. Fresh core was recovered from this intersection.

\section{Petrography}

Detailed petrography has shown the AN10 dyke to consist of abundant olivine and phlogopite phenocrysts plus rarer olivine and ilmenite macrocrysts, set in a fine-grained groundmass of clinopyroxene and phlogopite with subordinate amounts of interstitial serpentine, calcite and nepheline as well as discrete perovskite, spinel, ilmenite and apatite grains. Schorlomite garnet occurs in the contact samples.

Olivines occur as rare, large macrocrysts ( $4 \mathrm{~mm}$ in size) and smaller (< $1 \mathrm{~mm}$ ) phenocrysts with complex euhedral to subhedral shapes. All the olivines are totally serpentinised and carbonatised.

High $\mathrm{Mg}$, low $\mathrm{Cr}$ ilmenite macrocrysts occur up to $6 \mathrm{~mm}$ in size and correlate in composition with those in the surface ilmenite anomaly. Smaller matrix ilmenites tend to be poorer in $\mathrm{Mg}$. 
Phlogopite phenocrysts commonly consist of a weakly pleochroic core surrounded by a highly pleochroic mantle that is similar in pleochroism to interstitial groundmass phlogopite. The compositions of the mantle and groundmass phlogopites are enriched in $\mathrm{Al}_{2} \mathrm{O}_{3}$ and $\mathrm{TiO}_{2}$ but depleted in $\mathrm{FeO}$ relative to core compositions.

Diopside clinopyroxene occurs as acicular to tabular grains intimately intergrown with groundmass phlogopite, serpentine, calcite and nepheline.

Perovskites are relatively coarse and may occur intergrown with phlogopite, spinel and ilmenite.

Spinels are titanomagnetites with very low $\mathrm{Cr}_{2} \mathrm{O}_{3}$.

Serpentine and nepheline occur as interstitial groundmass minerals.

Spheroidal structures composed of calcite and amphibole occur throughout the specimens. These are considered to represent completely digested country rock microxenoliths as similar mineral associations are observed in partly replaced microxenoliths.

Within $10 \mathrm{~cm}$ of either contact schorlomite garnet occurs as red-brown, subhedral, poikilitic clots up to $1 \mathrm{~mm}$ in size. These are zoned with low-Ti cores and high-Ti rims.

The AN10 dyke is classified petrographically as an olivine lamprophyre probably of alnoitic affinity.

\section{Whole Rock Geochemistry}

Samples from across the AN10 dyke were analysed by XRF for major and trace elements. Results presented in Table 1 indicate that the rock is strongly undersaturated and magnesium-rich and shows strong similarities to rocks of the alnoite-melilitite-nephelinite series.

Geochronology

A relatively large number of mica separates were prepared from several specimens across the AN10 dyke. These were carefully cleaned and inspected and the freshest material analysed for $\mathrm{Rb}, \mathrm{Sr}$ and $\mathrm{Sr}$ isotope ratios. The data are plotted in Fig. 1 on a conventional isochron diagram which yields an age of $849 \pm 9 \mathrm{~m} . y$. with an initial ${ }^{87} \mathrm{Sr} /{ }^{86} \mathrm{Sr}$ ratio of .7036 .

\section{CONCLUSION}

The AN10 and ANl dykes were located by routine heavy mineral exploration for kimberlites. Both dykes produced strong surface anomalies of $\mathrm{Mg}$-rich ilmenite.

Drilling provided fresh core from AN10 on which petrological studies were undertaken. The dykes are olivine lamprophyres similar to the alnoite-melilitite-nephelinite suite of rocks. Dating of micas suggest an emplacement age of $849 \mathrm{~m}$. y. from a mantle source isotopically slightly depleted relative to Bulk Earth.

The criteria reviewed suggest that the alkalic ultrabasic dykes located near Norseman represent a previously unrecognised phase of late Proterozoic alkalic magmatism and that they are not associated with the early Proterozoic ultrabasic intrusives found in the general area.

\section{REFERENCES}

CLEMENT C.R. 1982. A comparative geological study of some major kimberlite pipes in the Northern Cape and Orange Free State, 2 vols. Unpubl. PhD thesis, University of Cape Town, Cape Town.

MOORE A.E. 1979. The geochemistry of olivine melilitites and related rocks of Namaqualand-Bushmanland, South Africa, 2 vols. Unpubl. PhD thesis, University of Cape Town, Cape Town. 
NORSEMAN, WEST AUSTRALIA. 1973. 1:250,000 Geological series - explanatory notes compiled by J.J. Doepel. Geological Survey of West Australia, Australian Government Publishing Service, Canberra.

ROCK N.M.S. 1986. The nature and origin of ultramafic lamprophyres: Alnoites and allied rocks, Journal of Petrology, vol. 27, Part 1, 155-196.

\section{Fig. 1}

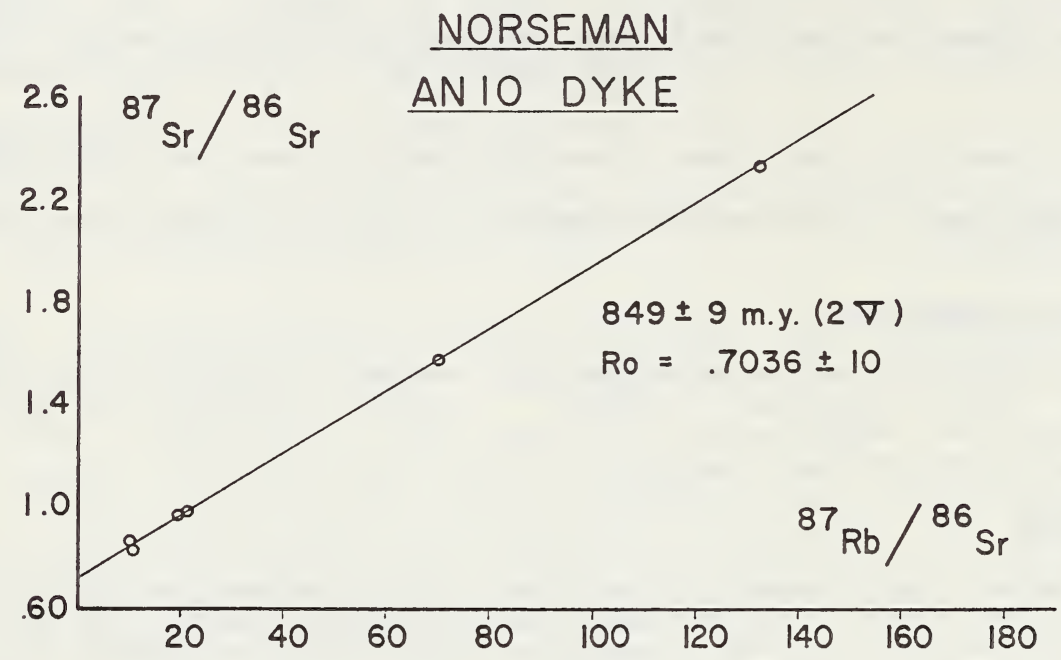

\section{TABLE 1}

1

$\mathrm{SiO}_{2}$

$\mathrm{TiO}_{2}$

$\mathrm{Al}_{2} \mathrm{O}_{3}$

$\mathrm{Fe}_{2} \mathrm{O}_{3}$

$\mathrm{MnO}$

$\mathrm{MgO}$

$\mathrm{CaO}$

$\mathrm{Na}_{2} \mathrm{O}$

$\mathrm{K}_{2} \mathrm{O}$

$\mathrm{P}_{2} \mathrm{O}_{5}$

\section{$\underline{2}$}

35.07

6.12

5.95

18. 12

.23

16.58

13.33

1.60

1.65

1.35

\section{3}

34.42

3.25

9.84

13. 58

.26

16.35

17.10

2.25

2.25

1.60

\section{4}

34.53

2.06

2.97

10.38

.18

33.80

12.50

.39

1.40

1.79
5

41.61

1.12

3.72

9.45

.22

31.43

7.58

.24

3.59

1.03

All data normalised volatile free and all $\mathrm{Fe}$ as $\mathrm{Fe}_{2} \mathrm{O}_{3}$.

1: Average of 4 samples from the AN10 dyke, this study.

2: Average Namaqualand melilitite-nephelinite (Moore, 1979).

3: Average of 55 melilite-rich alnoites (Rock, 1986).

4: Average Group 1 kimberlite (Clement, 1983).

5: Average Group 2 kimberlite. 